\title{
Lymphocyte cytotoxicity in systemic sclerosis: no increase on short-term culture with established human cell lines
}

\author{
J. K. WRIGHT, P. HUGHES, AND N. R. ROWELL \\ From the University Department of Medicine, Northern General Hospital, Sheffield, and the University \\ Department of Dermatology, General Infirmary at Leeds, Leeds
}

SUMMARY Lymphocyte cytotoxicity towards 4 established human epithelial and fibroblast cell lines was investigated in 18 patients with systemic sclerosis by means of both whole blood and peripheral blood mononuclear cells in short term $(18 \mathrm{~h}){ }^{51} \mathrm{Cr}$-release assays. No difference in the levels of cytotoxicity was found in patients compared with 25 normal controls, even when allowance was made for the severity of the disease and the sex of patients and controls. It is suggested that long-term (3-6 days) culture may be necessary to demonstrate the increased lymphocyte cytotoxicity originally described in the disorder.

\begin{abstract}
A high incidence of both autoantibodies ${ }^{12}$ and rheumatoid factor ${ }^{3}$ is a well recognised feature of systemic sclerosis. Interest in the possibility of an immunological pathogenesis for the disorder, however, has come principally from the observations of Trayanova et al. ${ }^{4}$ and Currie et al. ${ }^{5}$ that lymphocytes from patients with the disorder showed elevated levels of cytotoxicity towards cultured target cells. Additional impetus for this concept was provided by the recognition that graft-versus-host disease, initially in experimental animals ${ }^{6}$ and later in man, ${ }^{78}$ might be complicated by sclerodermatous lesions. However, an element of controversy has been introduced in to the literature by rather limited subsequent studies of lymphocyte cytotoxicity ${ }^{910}$ which have failed to confirm the original reports of Trayanova $e t$ $a l .{ }^{4}$ and Currie et al. ${ }^{5}$ The present investigation of lymphocyte cytotoxicity in systemic sclerosis, which utilised 4 widely differing established human cell lines, was undertaken, therefore, as part of a further series of studies of cytotoxic mechanisms in the disorder.
\end{abstract}

\section{Materials and methods}

Patients. Eighteen patients with systemic sclerosis ( 16 women, 2 men; mean age 53.56 \pm 4.04 years) were studied. Only 2 of the patients were receiving

Accepted tor publication 10 July 1981.

Correspondence to Dr J. K. Wright, Department of Medicine, Clinical Sciences Centre, Northern General Hospital, Sheffield S5 7AU. treatment with immunosuppressive drugs (prednisolone 5-10 mg daily). Raynaud's phenomenon and acrosclerosis were constant features, and all patients were assessed for the extent of systemic involvement by the disorder as previously described ${ }^{11}$ and were thus categorised as having 'severe' or 'mild' disease.

Controls. These consisted of 25 normal healthy volunteers (19 women, 6 men; mean age $34.96 \pm$ $2 \cdot 72$ years).

Cell lines. Three established human epithelial cell lines (Girardi heart, Intestine 407, L132) and one established human fibroblast line (MRC 5) were obtained from Flow Laboratories (Irvine, Scotland) and maintained in $75 \mathrm{~cm}^{2}$ glass culture bottles on Eagle's basal medium supplemented with $10 \%$ fetal bovine serum, nonessential amino acids, and antibiotics. Single cell suspensions were obtained by treating monolayers with $0 \cdot 1 \%$ trypsin (Sigma Chemical Co., London) in calcium magnesium-free Hanks's balanced salt solution with 20 mmol Hepes buffer $\mathrm{pH} 7 \cdot 2$ for $10 \mathrm{~min}$ at $37^{\circ} \mathrm{C}$.

Cytotoxicity assays. Target cells were labelled with ${ }^{51} \mathrm{Cr}$ as previously described ${ }^{11}$ and incubated in Eagle's basal medium with $10 \%$ fetal bovine serum at a concentration at $2 \times 10^{4}$ cells with either $5 \times 10^{5}$ peripheral blood mononuclear cells or $200 \mu \mathrm{l}$ whole blood. Triplicate cultures were maintained for 18 hours at $37^{\circ} \mathrm{C}$ and the 'percentage specific cytotoxicity' was then calculated from the ${ }^{51} \mathrm{Cr}$ release, as previously described. ${ }^{11}$ 
Statistical methods. Comparison of the cytotoxicity data in patients and control groups was made by the Mann-Whitney ranking test.

\section{Results}

The results of the cytotoxicity assays against the 4 established cell lines using both whole blood and peripheral blood mononuclear cells from patients with systemic sclerosis and controls are summarised in Table 1. Although levels of cytotoxicity were generally higher in whole blood assays, neither effector system revealed any difference between the patient and control groups. Although the data are not presented, analysis of the patients with systemic sclerosis in terms of 'severe' and 'mild' disease also failed to reveal any significant difference in levels of cytotoxicity from that found in controls. In view of reports that men have higher levels of spontaneous lymphocyte mediated cytotoxicity than women, ${ }^{12}$ a further comparison was made between female patients and the corresponding female controls, as shown in Table 2. Although there now appeared to be a trend for whole-blood assays from patients with

Table 1 Spontaneous lymphocyte cytotoxicity for established human target cells in patients with systemic sclerosis (SS) and controls

\begin{tabular}{|c|c|c|c|c|}
\hline \multirow{3}{*}{$\begin{array}{l}\text { Target } \\
\text { cell }\end{array}$} & \multicolumn{4}{|c|}{ Mean specific cytotoxicity $( \pm S E M)$ in } \\
\hline & \multicolumn{2}{|l|}{ WB assays } & \multicolumn{2}{|c|}{ PBM assays } \\
\hline & $\begin{array}{l}\text { Controls } \\
(n=25)\end{array}$ & $\begin{array}{l}\text { Total SS } \\
(n=18)\end{array}$ & $\begin{array}{l}\text { Controls } \\
(n=25)\end{array}$ & $\begin{array}{l}\text { Total SS } \\
(n=18)\end{array}$ \\
\hline $\begin{array}{l}\text { Girardi } \\
\text { Intestine- }\end{array}$ & $14 \cdot 7(1 \cdot 8)$ & $14 \cdot 7(2 \cdot 3)$ & $9 \cdot 1(0 \cdot 9)$ & $9 \cdot 4(1 \cdot 4)$ \\
\hline 407 & $12 \cdot 0(1 \cdot 8)$ & $14 \cdot 3(2 \cdot 7)$ & $5 \cdot 7(0.9)$ & $6 \cdot 8(1.2)$ \\
\hline L-132 & $16 \cdot 9(2 \cdot 7)$ & $19.9(3.9)$ & $9 \cdot 9(1 \cdot 5)$ & $9 \cdot 7(1 \cdot 6)$ \\
\hline MRC-5 & $12.9(1.9)$ & $8 \cdot 5(1 \cdot 6)$ & $7 \cdot 4(1.7)$ & $8 \cdot 1(1 \cdot 7)$ \\
\hline
\end{tabular}

WB: whole blood $200 \mu$ l. PBM: peripheral blood mononuclear cells $5 \times 10^{5}$. All target cells: $2 \times 10^{4}$.

Table 2 Spontaneous lymphocyte cytotoxicity for established human target cells in female patients with systemic sclerosis (SS) and female controls

\begin{tabular}{|c|c|c|c|c|}
\hline \multirow{3}{*}{$\begin{array}{l}\text { Target } \\
\text { cell }\end{array}$} & \multicolumn{4}{|c|}{ Mean specific cytotoxicity $( \pm S E M)$ in } \\
\hline & \multicolumn{2}{|l|}{$W B$ assays } & \multicolumn{2}{|c|}{ PBM assays } \\
\hline & $\begin{array}{l}\text { Female } \\
\text { controls } \\
(n=19)\end{array}$ & $\begin{array}{l}\text { Female } \\
S S \\
(n=16)\end{array}$ & $\begin{array}{l}\text { Female } \\
\text { controls } \\
(n=19)\end{array}$ & $\begin{array}{l}\text { Female } \\
S S \\
(n=16)\end{array}$ \\
\hline Girardi & $13 \cdot 7(2 \cdot 1)$ & $14 \cdot 8(2 \cdot 4)$ & $9 \cdot 1(0 \cdot 9)$ & $9 \cdot 5(1 \cdot 5)$ \\
\hline $\begin{array}{l}\text { Intestine- } \\
\quad 407\end{array}$ & $10 \cdot 2(1 \cdot 9)$ & $14 \cdot 3(2.9)$ & $4.9(0.9)$ & $6.9(1.3)$ \\
\hline L-132 & $14 \cdot 1(2 \cdot 9)$ & $20 \cdot 2(4 \cdot 2)$ & $9 \cdot 6(2 \cdot 0)$ & $9 \cdot 7(1.5)$ \\
\hline MRC-5 & $12 \cdot 7(2 \cdot 2)$ & $8 \cdot 1(1 \cdot 6)$ & $8 \cdot 1(2 \cdot 2)$ & $7 \cdot 6(1 \cdot 7)$ \\
\hline
\end{tabular}

WB: whole blood $200 \mu$ l. PBM: peripheral blood mononuclear cells $5 \times 10^{5}$. All target cells: $2 \times 10^{4}$. systemic sclerosis to show higher levels of cytotoxicity against the Intestine 407 and L132 cell lines than the controls, this did not reach statistical significance. Overall there was, once more, no difference in the levels of cytotoxicity between patients and control groups for any of the 4 established cell lines.

\section{Discussion}

This investigation, like the earlier attempts of Kondo et al. ${ }^{9}$ and Cooper and Friou, ${ }^{10}$ has failed to confirm the observations of both Trayanova et al. ${ }^{4}$ and Currie et al. ${ }^{5}$ that lymphocytes from patients with systemic sclerosis show increased cytotoxicity towards cultured target cells. As the range of target cells used by us was larger than in either of the other 2 attempts at confirmation, it is perhaps relevant to consider possible factors underlying the conflicting reports.

The origin and type of target cells used in all these studies is very likely to be of vital importance. Although Currie et al. ${ }^{5}$ used target cells that were predominantly of rat origin, the possibility that discrepant findings could have arisen as a result of species incompatibility is unlikely, as Trayanova et al. ${ }^{4}$ certainly used human target cells, as have all the subsequent attempts at confirmation. ${ }^{910}$ The use by us of established cell lines, in contrast to the primary fibroblasts used by Trayanova et al. ${ }^{4}$ cannot account for the differences, for both Kondo et al. ${ }^{9}$ and Cooper and Friou ${ }^{10}$ also used primary human fibroblast targets.

The period of incubation of lymphocytes with target cells, however, may also be very important in explaining the conflicting results. Both the original studies used morphological criteria to detect cytotoxicity, which was maximal after 3 to 6 days of culture in most instances. All the subsequent studies, however, have used shorter term ${ }^{51} \mathrm{Cr}$-release assays, and this difference may well underlie the differing pattern of results, as target cell sensitivity may differ in long- and short-term culture..$^{13}$ The conflicting patterns of cytotoxicity observed in prolonged and short-term assays may also be a reflection of the differing lymphocyte subpopulations exerting such cytotoxic effects. Short-term cytotoxicity assays are likely to show a considerable component of NK cell activity, whereas prolonged incubation may allow the development of activated T lymphocyte killing. ${ }^{14}$ In view of the fact that both experimental and human graft-versus-host disease can be complicated by the development of sclerodermatous lesions, ${ }^{6-8}$ continuing investigation of lymphocyte cytotoxicity would certainly be justified by prolonged periods of culture not only with primary and established cell lines but also with fractionated and enriched lymphocyte subpopulations. 
This investigation was supported by a grant from the Wellcome Trust.

\section{References}

${ }^{1}$ Beck J S, Anderson J R, Gray K G, Rowell N R. Antinuclear and precipitating auto-antibodies in progressive systemic sclerosis. Lancet 1963; ii: 1188-90.

2 Alarcon-Segovia D, Fishbein E, Garcia-Ortigoza E, EstradaParra S. Uracil-specific anti-RNA antibodies in scleroderma. Lancet 1975 ; i: $363-6$.

${ }^{3}$ Rothfield N F, Rodnan G P. Serum antinuclear antibodies in progressive systemic sclerosis (scleroderma). Arthritis Rheum 1968; 11: 607-17.

4 Trayanova T G, Sura V V, Svet-Moldavsky G J. Destruction of human cells in tissue culture by lymphocytes from patients with systemic lupus erythematosus. Lancet 1966; i: 452-4.

5 Currie S, Saunders M, Knowles M. Immunological aspects of systemic sclerosis: in vitro activity of lymphocytes from patients with the disorder. Br J Dermatol 1976; 84: 400-9.

- Stastny P, Stembridge V A, Ziff M. Homologous disease in the adult rat, a model for autoimmune disease. I. General features and cutaneous lesions. $J$ Exp Med 1963; 118: 635-48.

7 Van Vloten W A, Scheffer E, Dooren L J. Localised scleroderma-like lesions after bone marrow transplantation in man. Br J Dermatol 1977; 96: 337-41.
${ }^{8}$ Fenyk J R, Warkentin P I, Goltz R W, et al. Sclerodermatous graft-versus-host disease limited to an area of measles exanthem. Lancet 1978; i: 472-3.

${ }^{9}$ Kondo H, Rabin B S, Rodnan G P. Cutaneous antigenstimulating lymphokine production by lymphocytes of patients with progressive systemic sclerosis (scleroderma). J Clin Invest 1976; 58: 1388-94.

${ }^{10}$ Cooper S M, Friou G J. Cytotoxicity in progressive systemic sclerosis: no evidence for increased cytotoxicity against fibroblasts of different origin. J Rheumatol 1979; 6: 25-9.

${ }^{11}$ Wright J K, Hughes P, Rowell N R, Sneddon I B. Antibodydependent and phytohaemagglutinin-induced lymphocyte cytotoxicity in systemic sclerosis. Clin Exp Immunol 1979; 36: 175-82.

12 Santoli D, Trinchieri G, Moretta C, Zmijewski C M, Koprowski H. Spontaneous cell-mediated cytotoxicity in humans. Distribution and characterisation of the effector cell. Cell Exp Immunol 1978; 33: 309-18.

${ }^{13}$ Masucci M G, Masucci G, Klein E, Berthold W. Target selectivity of interferon-induced human killer lymphocytes related to their Fc receptor expression. Proc Natl Acad Sci USA 1980; 77: $3620-4$.

14 Masucci G, Poros A, Seeley J K, Klein E. In vitro generation of K562 killers in human T-lymphocytes subsets. Cell Immunol 1980; 52: 247-54. 